\title{
SENSITIVITAS ANTIBIOTIK BETALAKTAM TERHADAP BAKTERI HASIL ISOLAT KULTUR URINE PADA PENDERITA INFEKSI SALURAN KEMIH
}

\author{
Andi Fatmawati ${ }^{1)}$ \\ ${ }^{1)}$ Akademi Analis Kesehatan Muhammadiyah Makassar \\ Alamat Korespondensi : fatmawati.moe@gmail.com
}

\begin{abstract}
Abstrak
Antibiotik betalaktam telah digunakan secara luas terhadap penyakit infeksi saluran kemih (ISK) karena spektrum aktivitas antibakterinya yang cukup luas, mencakup bakteri gram positif dan gram negatif. Penelitian ini bertujuan untuk menguji sensitivitas antibiotik betalaktam,terhadap bakteri hasil isolat kultur urine penderita ISK Di Rumah Sakit Ibnu Sina Makassar berdasarkan standar NCCLS. Hasil penelitian menunjukkan bahwa hasil identifikasi gram dan uji biokimia dari hasil spesimen urine penderita ISK didapatkan hasil isolat bakteri Enterobacter agglomerans dan Staphylococcus saprophyticus. Dari ketiga antibiotik betalaktam seftazidim, sefotaksim dan seftriakson, bersifat sensitif terhadap pertumbuhan Enterobacter agglomerans. Sedangkan Seftriakson kurang sensitif, Seftazidim bersifat sensitif, dan sefotaksim bersifat resisten terhadap pertumbuhan Staphylococcus saprophyticus .
\end{abstract}

Kata Kunci: Antibiotik Betalaktam, Enterobacter agglomerans, Isolat Kultur, Penderita ISK, Staphylococcus saprophyticus

\section{PENDAHULUAN}

Di negara yang sudah maju 13-37\% dari seluruh penderita yang dirawat di rumah sakit mendapatkan antibiotik baik secara tunggal maupuan kombinasi, sedangkan di negara berkembang 30-80\% penderita yang dirawat di rumah sakit mendapatkan antibiotik. Penggunaan antibiotik yang tidak rasional sangat banyak dijumpai baik di negara maju maupun berkembang.

Pada awalnya istilah yang digunakan adalah antibiosis yang berarti substansi yang dapat menghambat pertumbuhan organisme hidup yang lain, dan berasal dari mikroorganisme. Namun pada perkembangannya, antibiosis ini disebut sebagai antibiotik dan istilah ini tidak hanya terbatas untuk substansi yang berasal dari mikroorganisme, melainkan semua substansi yang diketahui memiliki kemampuan untuk menghalangi pertumbuhan organisme lain khususnya mikroorganisme. Untuk bakteri, pengertian antibiotik berkembang menjadi bahan kimia yang dapat membunuh bakteri-bakteri, atau yang lebih dikenal dengan sebutan bakterisidal, atau menghambat perkembangan bakteri atau bakteriostatik (Chandra, 2008).

Penggunaan antibiotik tentu diharapkan mempunyai dampak positif, akan tetapi penggunaan antibiotik yang tidak rasional akan menimbulkan dampak negatif. Dampak negatif dari penggunaan antibiotik yang tidak rasional antara lain muncul dan berkembangnya bakteri yang resisten terhadap antibiotik, munculnya penyakit akibat superinfeksi bakteri resisten, terjadinya toksisitas atau efek samping obat,sehingga perawatan penderita menjadi lebih lama, biaya pengobatan menjadi lebih mahal, dan akhirnya menurunnya kualitas pelayanan kesehatan .

Infeksi saluran kemih (ISK) adalah infeksi bakteri yang terjadi pada saluran kemih (mencakup organ-organ saluran kemih, yaitu ginjal,ureter, kandung kemih, dan uretra). Infeksi saluran kemih di Indonesia insiden dan prevalensinya masih cukup tinggi. Keadaan ini tidak terlepas dari tingkat dan taraf kesehatan masyarakat Indonesia yang masih jauh dari standart dan tidak meratanya tingkat kehidupan sosial ekonomi, yang mau 
tidak mau berdampak langsung pada kasus infeksi saluran kemih di Indonesia. Penyakit Infeksi saluran kemih merupakan masalah kesehatan masyarakat di Indonesia yang perlu mendapatkan perhatian yang serius. Diperkirakan $8 \%$ anak wanita dan $2 \%$ anak laki - laki pernah mengalami ISK pada masa kanak - kanaknya. Insiden ISK belum diketahui dengan pasti (Subandiyah, 2004).

Mikroorganisme yang sering menyebabkan ISK antara lain Escherichia coli (merupakan mikroorganisme yang paling sering diisolasi dari pasien dengan infeksi simtomatik maupun asimtomatik), Proteus sp, Klebsiella sp, Enterobacter $s p, \quad$ Citrobacter sp. Infeksi yang disebabkan Pseudomonas $s p$ dan mikroorganisme lainnya seperti Staphylococcus jarang dijumpai kecuali pasca kateterisasi. Mikroorganisme lain yang kadang-kadang dijumpai sebagai penyebab ISK adalah Chlamydia dan Mycoplasma (Praktika, 2009).

Sasaran terapi pada infeksi saluran kemih adalah mikroorganisme penyebab infeksi. Oleh karena itu, pengobatan ISK sebagian besar menggunakan antibiotik. Pemilihan antibiotik untuk pengobatan didasarkan pada tingkat keparahan, tempat terjadinya infeksi dan jenis mikroorganisme yang menginfeksi (Endriani,2009).

Saat ini telah banyak terjadi resistensi bakteri penyebab ISK terhadap antibakteri sehingga angka kesakitan semakin tinggi. Perubahan pola resistensi bakteri penyebab ISK terjadi lebih cepat dibanding infeksi lainnya. Meskipun telah banyak yang melaporkan bahwa pola resistensi bakteri penyebab ISK telah terjadi, tetapi mengingat perbedaan tempat dan waktu penelitian yang dilakukan kemungkinan pola resistensi bakteri penyebab ISK terhadap berbagai antibiotik juga berubah. Oleh karena itu, sangat penting untuk memantau pola resistensi bakteri penyebab ISK terhadap berbagai antibakteri secara berkesinambungan disetiap institusi kesehatan. Berdasarkan uraian diatas dapat dilihat betapa pentingnya untuk mengetahui pola resistensi bakteri penyebab ISK terhadap antibakteri terutama untuk penanganan ISK yang lebih rasional (Endriani,2009).

$$
\text { Penelitian yang dilakukan }
$$

Noorhamdani et al., (1996) menentukan bahwa resistensi Escherichia coli terhadap ampicilin dan amoxycilin di RSUD Dr. Saiful Anwar Malang mencapai $70 \%$. Antibakteri sefalosporin generasi pertama sudah lama dan sering digunakan untuk terapi ISK sehingga bisa menyebabkan terjadinya resistensi. Antibakteri sefalosporin generasi kedua efektif terutama terhadap bakteri Gram negatif, sedangkan sefalosporin generasi ketiga (seperti cefadroxil,cefriaxone, dan lain-lain) aktif dan mempunyai spektrum yang luas terhadap Enterobacteriaceae, termasuk strain penghasil penisilinase atau strain yang resisten terhadap sefalosporin generasi kedua. Namun, dengan adanya berbagai mekanisme bakteri dalam menyebabkan resistensi, bakteri-bakteri tersebut dapat saja menjadi resisten. Sefalosporin generasi ke tiga seperti ceftazidime mempunyai aktivitas yang tinggi terhadap Pseudomonas sp penyebab ISK. (Endriani, 2009).

Antibiotik jenis penicillin, cephalosporin, monobactam dan carbapenem merupakan antibiotik golongan betalaktam, karena memiliki cincin beta-laktam pada strukturnya. Antibiotika golongan sefalosporin generasi ke-3 telah digunakan secara luas pada pengobatan berbagai penyakit infeksi. Juga digunakan pada pengobatan ISK (Infeksi Saluran Kemih). Hal ini disebabkan karena spektrum aktivitas anti bakterinya yang cukup luas, mencakup bakteri Gram negatif dan Gram positif. Sefalosporin generasi ketiga memiliki aktifitas lebih kuat dan lebih luas dari generasi sebelumnya terhadap kuman Gram-negatif. Produksi dari enzim betalaktamase adalah penyebab utama terjadinya resistensi terhadap antibiotik golongan beta-laktam. Enzim betalaktamase memutus cincin amida pada cincin beta-laktam, sehingga mengakibatkan antibiotik menjadi tidak aktif. (Firizky, 2013). 
Berdasarkan uraian di atas, maka penelitian ini bertujuan untuk menentukan sensitivitas antibiotik betalaktam terhadap bakteri hasil isolat kultur urine pada penderita ISK di Rumah Sakit Ibnu Sina Makassar berdasarkan standar NCCLS (National Commite For Clinical Laboratory Standard).

\section{PROSEDUR PENELITIAN}

\section{Alat dan Bahan}

Alat-Alat yang digunakan dalam penelitian ini adalah autoklaf, botol steril (penampung urin), cawan petri, inkubator, lampu spritus, lamina air flow (LAF), mistar geser, ose bulat, pingset, rak tabung, sendok tanduk, spoit, pipet steril, tabung reaksi, timbangan analitik.

Bahan-bahan yang digunakan adalah aquadest steril, alkohol 96\%, aluminum foil, bakteri hasil isolat kultur urine, disk antibiotik, kapas lidi steril / cutton bad, $\mathrm{NaCl}$ steril, Medium Mac Conkey, Medium Muller Hinton Agar, Medium Nutrien agar, $\mathrm{NaCl}$ fisiologis 0,9 $\%$, Sampel urine (pagi /segar).

\section{Prosedur Penelitian}

\section{Pengambilan spesimen urin}

Spesimen urin diperoleh dari pasien ISK (Infeksi Saluran Kemih) di perawatan rawat inap Rumah Sakit Ibnu Sina Makassar, diambil melalui kantong kateter (penampungan urin) pasien, diambil menggunakan spoit steril dengan tindakan antisepsis pada daerah kateter yang akan ditusuk, tempat penusukan kateter sedekat mungkin dengan ujung kateter yang berada di dalam kandung kemih (ujung distal), kemudian dimasukkan pada pot atau botol steril.

\section{Pembuatan Medium}

\section{Medium Muller Hinton Agar untuk $250 \mathrm{~mL}$}

Bahan-bahan yang akan digunakan ditimbang 8,5 g, kemudian dilarutkan dalam air sebanyak $250 \mathrm{ml}$ dengan bantuan pemanasan hingga semua bahan terlarut sempurna, lalu di cek $\mathrm{pH}$ 7,4 dan disterilkan dengan otoklaf pada suhu $121^{\circ} \mathrm{C}$ selama 15 menit.

Medium Nutrien Agar (NA) untuk 250 mL

Ditimbang 5,75 gram dan dimasukkan kedalam Erlemeyer lalu dilarutkan dengan air suling sedikit demi sedikit dibantu dengan sedikit pemanasan semua bahan larut diatur pada $\mathrm{pH}$ 6,8 dan dicukupkan volumenya dengan air suling $250 \mathrm{ml}$ disterilkan dalam otoklaf pada suhu $121^{\circ} \mathrm{C}$ selama 15 menit dengan tekanan 2 atmosfir.

\section{Medium Mac Conkey Agar untuk 250} ml

Ditimbang 20,6 gram mac conkey agar, lalu dimasukkan kedalam 2 erlemeyer 250 $\mathrm{ml}$ masing-masing sebanyak $200 \mathrm{ml}$, kemudian ditambahkan aquadest masingmasing sebanyak $200 \mathrm{ml}$, lalu dipanaskan diatas pemanas sampai larut sempurna, setelah itu ditutup dengan penutup ikat(bundle), lalu disterilkan dengan autoklaf pada suhu $121^{\circ} \mathrm{C}$ selama 15 menit, kemudian dituangkan kedalam cawan plate, lalu dibungkus dengan kertas, setelah itu media siap digunakan.

\section{Persiapan Isolasi Bakteri dari Sampel} Urin

Pertama-tama sampel spesimen urin yang ada didalam botol,diambil sebanyak 0,5 $\mathrm{ml}$ dan diteteskan dalam media Nutrien Agar dan Mac Conkey, lalu diratakan, kemudian dimasukkan dalam inkubator selama 24 jam dengan suhu $37^{\circ} \mathrm{C}$, pada saat bakteri tumbuh pada media Nutrien Agar atau pada medium Mac Conkey dilanjutkan pengujian secara mikroskopik dengan cara diambil satu koloni yang ada, lalu dilakukan test pewarnaan gram dan uji biokimia untuk mengetahui adanya gram positif dan gram negatif.

\section{Penyiapan Kultur Murni Mikroba Uji Isolasi Bakteri}

Bakteri uji yang digunakan adalah bakteri hasil isolat murni kultur urin,diambil satu ose, lalu diinokulasi dengan cara digoreskan pada Medium Nutrien Agar (NA) diinkubasi selama 24 jam pada suhu $37^{\circ} \mathrm{C}$.

\section{Pewarnaan Gram}

Kaca objek dibersihkan dengan alkohol sehingga bebas dari lemak, difiksasi di atas lampu spiritus sampai kering,beri satu tetes $\mathrm{NaCl}$ fisiologis. Bakteri dari media NA diambil dengan jarum ose,diletakkan pada tetesan $\mathrm{NaCl}$ fisiologis,campur hingga merata. Biarkan mengering diudara sebentar dan fiksasi 
diatas api. Tetesi 2-3 tetes larutan kristal violet, biarkan selama 1 menit, bilas dengan air mengalir. Tetesi larutan lugol satu tetes dan dibiarkan selama 1 menit, dibilas dengan air mengalir, preparat dibilas dengan alkohol 96\% selama 30 detik,cuci dengan air mengalir. Terakhir ditetesi dengan safranin dan dibiarkan selama 1 menit lalu dibilas dengan air mengalir dan dikeringkan. Amati di bawah mikroskop pembesaran 100x dengan oil emersi. Warna ungu untuk bakteri gram positif dan warna merah untuk bakteri gram negatif.

\section{Uji Biokimia}

Identifikasi bakteri dengan uji biokimia didasarkan pada Uji TSIA, Uji Sitrat, Uji MR-VP, Uji SIM. Pengidentifikasian bakteri didasarkan pula dari jenis bakteri (bakteri gram positif atau bakteri gram negatif).

\section{Pengujian Kepekaan Antibiotik Terhadap Bakteri Uji}

Pengujian kepekaan antibiotik dilakukan dengan metode difusi Kirby Bauer yang direkombinasikan oleh National Committee For Clinical Laboratory Standard (NCCLS):

Media Muller Hinton Agar dituang secara aseptis kedalam cawan petri steril sebanyak $20 \mathrm{ml}$ dibiarkan sampai memadat. Setelah memadat,dengan kapas lidi steril di ambil suspensi inokulum yang berumur 24 Jam diusapkan secara merata pada permukaan medium Muller
Hinton Agar didiamkan selama 15 menit pada suhu kamar. Di letakkan paper disk antibiotik seftazidim, seftriakson, sefotaksim dengan pinset steril dan sedikit di tekan. Diatur jarak antara pusat ke pusat paper disk, jarak dari pinggir cawan petri minimal $15 \mathrm{~mm}$. Diamkan selama 15 menit kemudian diinkubasi dalam inkubator pada suhu $37^{\circ} \mathrm{C}$ selama 24 jam. Di ukur diameter zona hambatan antibiotika seftazidim, seftriakson, sefotaksim. Perlakuan dilakukan sebanyak 3 kali.

Pengamatan dan Pengukuran Diameter Hambatan

Pengamatan dan pengukuran diameter hambatan dilakukan setelah masa inkubasi 1 x 24 jam pada suhu $37^{\circ} \mathrm{C}$ dengan menggunakan mistar geser.

\section{Pengumpulan Dan Analisa Data}

Untuk menentukan resisten, intermediate dan sensitif, hasil zona hambatan yang diperoleh masing-masing antibiotika dibandingkan dengan nilai kritis resisten, intermediate dan sensitifdari rekombinasi Nasional Committe For Clinical Laboratory Standard (NCCLS).

\section{HASIL DAN PEMBAHASAN}

\section{Hasil Penelitian}

Hasil penelitian mengenai uji sensitivitas antibiotik betalaktam terhadap bakteri hasil isolat kultur urine pada penderita ISK di Rumah Sakit Ibnu Sina Makassar selengkapnya dapat dilihat pada tabel berikut:

Tabel 1. Hasil Identifikasi Bakteri Hasil Isolat Kultur urine pada penderita ISK di Rumah Sakit Ibnu Sina Makassar

\begin{tabular}{|c|c|c|c|c|c|c|c|}
\hline \multirow[b]{2}{*}{ Spesimen } & \multirow{2}{*}{$\begin{array}{c}\text { Pewarnaan } \\
\text { Gram }\end{array}$} & \multirow{2}{*}{$\begin{array}{l}\text { Bentuk } \\
\text { Morfologi }\end{array}$} & \multicolumn{4}{|c|}{ Uji Biokimia } & \multirow[b]{2}{*}{ Identifikasi } \\
\hline & & & TSIA & $\begin{array}{l}\text { MR- } \\
\text { VP }\end{array}$ & SIM & Citrat & \\
\hline A & $\begin{array}{l}\text { Gram } \\
\text { negatif }\end{array}$ & Basil & $\begin{array}{l}\text { Slant (+) } \\
\text { Butt (+) } \\
\text { Gas(-) } \\
\mathrm{H}_{2} \mathrm{~S}(-)\end{array}$ & - & $\begin{array}{l}\text { Indol (-) } \\
\text { Motility(+) } \\
\mathrm{H}_{2} \mathrm{~S}(-)\end{array}$ & + & $\begin{array}{l}\text { Enterobacter } \\
\text { agglomerans }\end{array}$ \\
\hline B & Gram positif & Coccus & $\begin{array}{l}\text { Butt (+) } \\
\text { Gas(-), } \\
\mathrm{H}_{2} \mathrm{~S}(-)\end{array}$ & - & $\begin{array}{l}\text { Indol (-) } \\
\text { Motility(+) } \\
\mathrm{H}_{2} \mathrm{~S}(-)\end{array}$ & - & $\begin{array}{l}\text { Staphylococus } \\
\text { saprophyticus }\end{array}$ \\
\hline
\end{tabular}

Tabel 2. Hasil pengukuran diameter hambatan $(\mathrm{mm})$ antibiotik betalaktam terhadap bakteri Enterobacter agglomerans hasil isolat kultur urine 
penderita ISK Di Rumah Sakit Ibnu Sina Makassar dengan inkubasi 1 x 24 jam pada suhu $37^{\circ} \mathrm{C}$

\begin{tabular}{cclccc}
\hline Perlakuan & $\begin{array}{c}\text { Bakteri Hasil } \\
\text { Isolat }\end{array}$ & $\begin{array}{c}\text { Jenis } \\
\text { Antibiotik }\end{array}$ & $\begin{array}{c}\text { Potensi } \\
\text { Disk } \\
(\mu \mathrm{g})\end{array}$ & $\begin{array}{c}\text { Zona } \\
\text { Hambatan } \\
(\mathrm{mm})\end{array}$ & Interpretasi \\
\hline \multirow{2}{*}{1} & $\begin{array}{c}\text { Enterobacter } \\
\text { agglomerans }\end{array}$ & Seftazidim & 30 & 27 & Sensitive \\
& Sefotaksim & 30 & 30 & Sensitive \\
& Seftriakson & 30 & 24 & Sensitive \\
\hline \multirow{2}{*}{2} & Enterobacter & Seftazidim & 30 & 26 & Sensitive \\
& agglomerans & Sefotaksim & 30 & 29 & Sensitive \\
& Enterobacter & Seftriakson & 30 & 23 & Sensitive \\
\hline \multirow{2}{*}{3} & Seftazidim & 30 & 26 & Sensitive \\
& agglomerans & Sefotaksim & 30 & 30 & Sensitive \\
& & Seftriakson & 30 & 24 & Sensitive \\
\hline
\end{tabular}

Tabel 3. Hasil pengukuran diameter hambatan $(\mathrm{mm})$ antibiotik betalaktam terhadap bakteri Staphylococcus saprophyticus hasil isolat kultur urine penderita ISK Di Rumah Sakit Ibnu Sina Makassar dengan inkubasi 1 x 24 jam pada suhu $37^{\circ} \mathrm{C}$

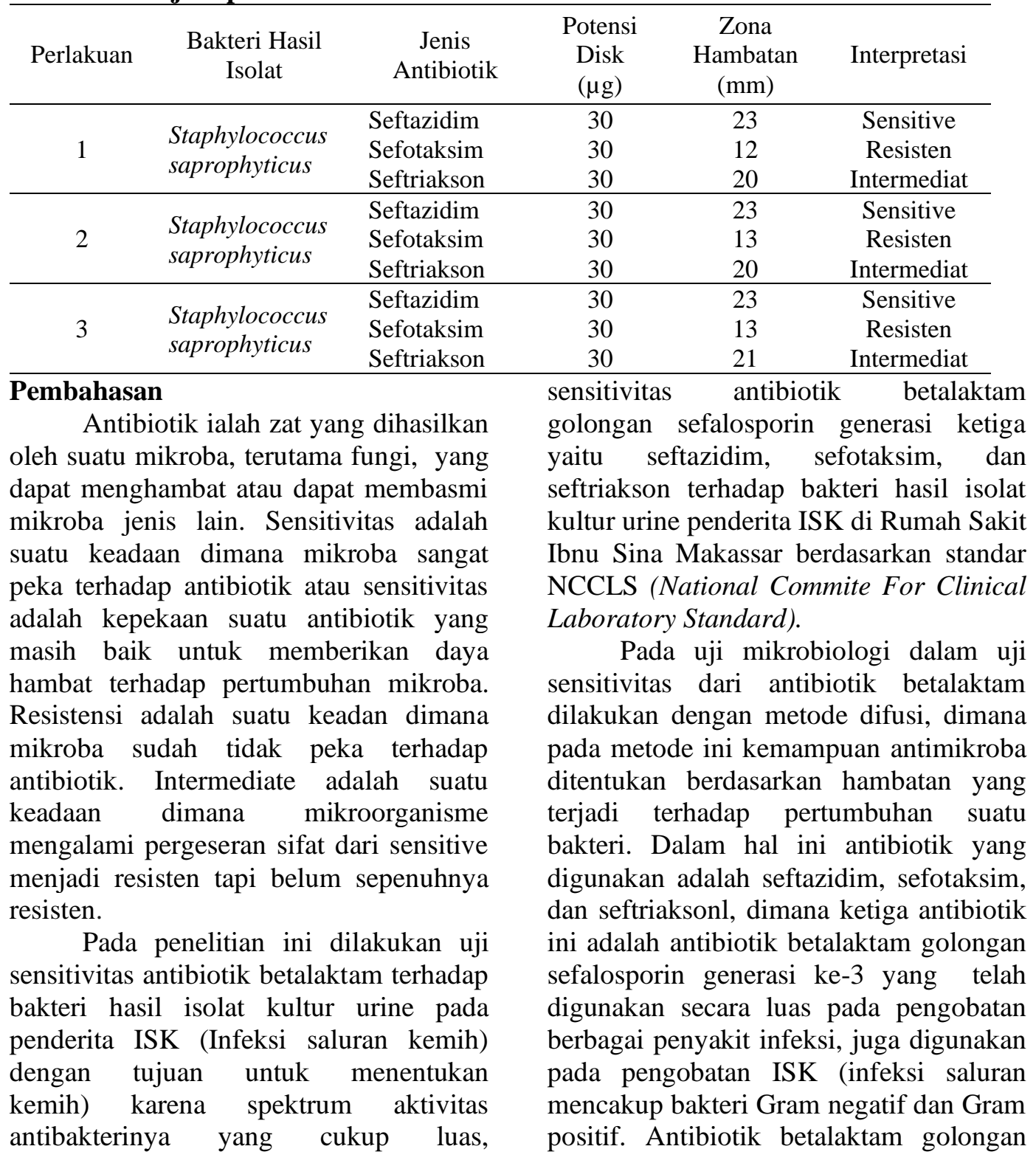


sefalosporin generasi ketiga ini memiliki mekanisme kerja dengan menghambat sintesis dinding sel bakteri dengan berikatan satu atau lebih ikatan protein yang selanjutnya akan menghambat tahap transpeptidase sintesis peptidoglikan dinding sel bakteri sehingga menghambat biosintesis dinding sel.

Pada penelitian ini bakteri yang digunakan adalah hasil isolat yang didapatkan dari spesimen urine yang diperoleh dari pasien ISK (infeksi saluran kemih) di Rumah Sakit Ibnu Sina Makassar dengan kriteria inklusi adalah pasien yang terdiagnosa ISK oleh bagian Spesialis Urologi Rumah Sakit Ibnu Sina Makassar yang terdapat di perawatan rawat inap. Dari hasil isolasi bakteri yang ditumbuhkan pada media Nutrien Agar dan dilanjutkan pada Mac Conkey Agar untuk menghambat pertumbuhan bakteri gram positif disebabkan oleh adanya garam empedu dan kristal violet sehingga yang tumbuh hanya bakteri gram negatif. Pada media ini memperlihatkan koloni yang berwarna merah bata dan dikelilingi oleh endapan garam empedu. Endapan ini di sebabkan oleh penguraian laktosa menjadi asam yang bereaksi dengan garam empedu, lalu dilanjutkan dengan uji biokimia. Uji biokimia yang dilakukan yaitu uji MR-VP, uji TSIA, uji SIM, dan uji Citrat.

Uji MR-VP ini dilakukan untuk menentukan organisme yang memproduksi dan mengelola asam dan produk-produknya dari hasil fermentasi glukosa, memperlihatkan kemampuan sistem buffer dan menentukan organisme yang menghasilkan produk netral (asetil metal karbinol atau aseton) dari hasil fermentasi glukosa, dengan adanya indikator methyl red yang berwarna merah pada suasana asam akan tetap menjadi warna merah pada $\mathrm{pH} 4,4$ dan berubah kuning pada $\mathrm{pH}$ 6,2. Pada spesimen A dan B tidak terjadi perubahan warna merah. Uji TSIA adalah untuk mengetahui organisme yang dapat memfermentasi glukosa, sukrosa dan/atau laktosa dengan atau tanpa menghasilkan antibiotik sefotaksim dengan rata - rata zona hambat ketiga perlakuan sebesar gas, juga untuk mengetahui kemampuan organisme dalam menghasilkan hydrogen sulfida dari thiosulfate dalam kondisi asam hasilnya memperlihatkan warna kuning pada bagian slant atau butt sebagai reaksi asam yang dihasilkan dengan phenol red. Pada spesimen A menunjukkan warna kuning pada pada bagian dasar (butt) dan miring (slant), tidak menghasilkan gas dan hydrogen sulfida. Pada spesimen B menunjukkan warna kuning pada bagian dasar (butt), tidak menghasilkan gas dan hydrogen sulfida. Uji SIM digunakan untuk mengetahui produksi indol, produksi hydrogen sulfida, dan pergerakan/motilitas dengan adanya reagen kovac's, indol menunjukkan warna merah, hydrogen sulfida warna hitam, dan untuk motilitas adanya penyebaran yang berwarna putih dari titik awal penanaman. Pada spesimen A dan B, indol dan hydrogen sulfida menunjukkan hasil yang negatif, dan untuk motilitas menunjukkan hasil positif. Uji Citrat dilakukan untuk untuk mengetahui apakah suatu organisme dapat menggunakan sitrat sebagai satu-satunya sumber karbon. Hasilnya jika $\mathrm{pH}$ indikator bromthymol biru berubah hijau menjadi biru tua jika terjadi peningkatan $\mathrm{pH}$ menjadi basa. Hanya mikroba yang mempunyai enzim citrat permiase yang dapat mentransport citrat ke dalam selnya untuk dikatalis. Pada spesimen A terjadi perubahan warna hijau menjadi biru tua, sedangkan pada spesimen B tidak terjadi perubahan warna dari hijau menjadi biru tua. Dari hasil uji biokima untuk spesimen A diidentifikasi Enterobacter agglomerans, dan untuk spesimen B Staphlococcus saprophyticus.

Hasil penelitian yang telah dilakukan didapatkan hasil yakni untuk hasil pengukuran diameter zona hambatan (mm) ketiga antibiotik terhadap pertumbuhan Enterobacter agglomerans dengan inkubasi pada suhu $37^{\circ} \mathrm{C}$ selama 1 x 24 jam yaitu untuk antibiotik seftazidim dengan rata - rata zona hambat ketiga perlakuan sebesar 26,33 $\mathrm{mm}$, menunjukkan interpretasi sensitive. Untuk 29,66 mm menunjukkan interpretasi sensitive. Untuk antibiotik seftriakson 
dengan rata - rata zona hambat ketiga perlakuan sebesar 23,66 $\mathrm{mm}$ menunjukkan interpretasi sensitive. Dengan demikian, menunjukkan bahwa ketiga antibiotik betalaktam golongan sefalosporin generasi ketiga tersebut bersifat sensitive terhadap pertumbuhan Enterobacter agglomerans dengan inkubasi pada suhu $37^{\circ} \mathrm{C}$ selama 1 × 24 jam. Hal ini dikarenakan kemampuan antibiotik betalaktam seftazidim, sefotaksim, dan seftriakson dalam membunuh bakteri Enterobacter agglomerans dengan cara menginhibisi sintesa dinding sel. Proses pembentukan dinding sel terjadi reaksi transpeptidase yang dikatalisis oleh enzim transpeptidase dan menghasilkan ikatan silang antara dua rantai peptida-glikan. Enzim transpeptidase yang terletak pada membran sitoplasma bakteri tersebut dapat mengikat antibiotik betalaktam sehingga menyebabkan enzim tidak mampu mengkatalisis reaksi transpeptidase walaupun dinding sel tetap terbentuk. Dinding sel yang terbentuk tidak memiliki ikatan silang dan peptidoglikan yang terbentuk tidak sempurna sehingga lebih lemah dan mudah terdegradasi, dengan demikian bakteri yang kehilangan dinding selnya akan lisis dan mati.

Untuk hasil pengukuran diameter zona hambatan $(\mathrm{mm})$ ketiga antibiotik terhadap pertumbuhan Staphylococus sapropiticus dengan inkubasi pada suhu $37^{\circ} \mathrm{C}$ selama 1 x 24 jam yaitu untuk antibiotik seftazidim dengan rata - rata zona hambat ketiga perlakuan sebesar 23 $\mathrm{mm}$, menunjukkan interpretasi sensitive. Untuk antibiotik sefotaksim dengan ratarata zona hambat ketiga perlakuan sebesar 12,66 mm, menunjukkan interpretasi resisten. Untuk antibiotik seftriakson dengan rata - rata zona hambat ketiga perlakuan sebesar 20,33 $\mathrm{mm}$, menunjukkan interpretasi intermediat. Hasil tersebut menunjukkan bahwa dari ketiga antibiotik tersebut hanya antibiotik seftazidim yang sensitive terhadap pertumbuhan Staphylococcus sedangkan terhadap pertumbuhan Staphylococcus saprophyticus, seftazidim saprophyticus dengan inkubasi pada suhu $37^{\circ} \mathrm{C}$ selama 1 x 24 jam, sedangkan antibiotik sefotaksim bersifat resisten terhadap pertumbuhan Staphylococcus saprophyticus dan antibiotik seftriakson bersifat intermediate terhadap pertumbuhan Staphylococcus saprophyticus dengan inkubasi pada suhu $37^{\circ} \mathrm{C}$ selama $1 \times 24$ jam. Beberapa bakteri diketahui memiliki resistensi terhadap antibiotik betalaktam, hal ini terbukti dari hasil penelitian yang memperjelas bahwa antibiotik sefotaksim telah bersifat resisten dan antibiotik seftriakson bersifat intermediat terhadap pertumbuhan Staphylococcus saprophyticus. Kemungkinan tumbuhnya bakteri yang resisten terhadap antibiotik ini karena adanya kemampuan dekstruksi antibiotik dengan adanya enzim betalaktamase yang dihasilkan oleh Staphylococcus saprophyticus yang mampu memecah cincin betalaktam sehingga antibiotik tersebut tidak aktif.

Hasil analisis statistika menggunakan metode rancangan acak lengkap (ANOVA) memperlihatkan bahwa pada zona hambat antibiotik Seftazidim, Sefotaksim, dan Seftriakson menunjukan ada perbedaan efek (signifikan) dari tiap perlakuan terhadap Enterobacter agglomerans dan Staphylococcus saprophyticus sehingga dilanjutkan pada uji rentang NewmannKeuls. Untuk zona hambat antibiotik A (Seftriakson) terhadap B (Seftazidim), A terhadap C (Sefotaksim), dan B terhadap $\mathrm{C}$, menunjukkan hasil yang signifikan terhadap Enterobacter agglomerans. Begitu pula untuk zona hambat antibiotik A (Sefotaksim) terhadap B (Seftriakson), A terhadap C (Seftazidim), dan B terhadap $\mathrm{C}$ menunjukkan hasil yang signifikan terhadap Staphylococus saprophyticus.

\section{KESIMPULAN DAN SARAN}

Dari hasil penelitian dan pembahasan maka dapat disimpulkan bahwa antibiotik betalaktam: seftazidim, sefotaksim, dan seftriakson bersifat sensitif terhadap pertumbuhan Enterobacter agglomerans, bersifat sensitif, sefotaksim resisten dan seftriakson intermediet. 
Disarankan peneliti selanjutnya untuk meneliti lebih lanjut tentang sensitivitas antibiotik lain terhadap Enterobacter agglomerans dan Staphylococcus saprophyticus.

\section{DAFTAR PUSTAKA}

Anggara, A. 2013. Uji Biokimia Mikroba, Jurnal Academia. Universitas UBAYA.

Arif, M. 2000. Kapita Selekta Kedokteran Edisi Ketiga. Jakarta: Penerbit Buku Kedokteran.

Aslam. M. 2003. Farmasi Klinis Menuju Pengobatan Rasional dan Penghargaan Pilihan Pasien. Jakarta: Penerbit PT Elex Media Komputindo, Kelompok Gramedia.

Djide, N. 2003. Mikrobiologi Farmasi. Makassar: Universitas Hasanuddin.

Endriani, et.al. 2009. Pola Resistensi Bakteri Penyebab Infeksi Saluran Kemih (ISK) Terhadap Antibakteri Di Pekanbaru. Pekanbaru: Bagian Mikrobiologi, Fakultas Kedokteran Universitas Riau.

Firizky, F. 2013. Pola Kepekaan Escherichia coli dan Klebsiella sp. Terhadap Antibiotik Sefalosporin Periode Tahun 2008-2012 Di Bandar Lampung. Bandar Lampung: Fakultas Kedokteran Universitas Lampung.

Ganiswarna, S. 1995 Farmakologi dan Terapi, Edisi 4. Jakarta: Bagian Farmakologi Fakultas Kedokteran Universitas Indonesia.

Maksum, M.R. 2009. Betalaktam. Bogor: Institut Pertanian Bogor.

Maulina, M. 2012. Pengertian Urine. Aceh: Laboratorium Analisis Kesehatan Aceh.

Mirawati, T., et. al. 2004. Hasil uji resistensi bakteri terhadapberbagai antibiotik di laboratorium mikrobiologi klinik. Jakarta.

Novi, P.W. 2009. Rasionalitas Penggunaan Antibiotik Pada Pasien Infeksi Saluran Kemih Pada Bangsal Penyakit Dalam di RSUP
Dr. Kariadi Semarang Tahun 2008.

Semarang: Fakultas Kedokteran

Universitas Diponegoro.

Pelczar, M.J., Chan, E.C.S. 1986. Dasar-

Dasar Mikrobiologi. Jakarta:

Universitas Indonesia Press.

Sudoyo, A.W., et.al. 2006. Buku Ajar Ilmu Penyakit Dalam Jilid II, Edisi IV. Jakarta: Pusat Penerbitan Departemen Ilmu Penyakit Dalam Fakultas Kedokteran UniversitasIndonesia. 